\title{
Weaning strategies to improve productivity and animal welfare in zebu (Bos indicus) and water buffaloes (Bubalus bubalis)
}

\author{
Agustín Orihuela ID. Daniel Mota-Rojas (D. Fabio Napolitano iD
}

A Orihuela (Corresponding author)

Facultad de Ciencias Agropecuarias, Universidad Autónoma del Estado de Morelos, Cuernavaca, Morelos, México.

\section{Mota-Rojas}

Neurophysiology, behavior and assessment of welfare in domestic animals, Department of Animal Production and Agriculture, Universidad Autónoma Metropolitana (UAM), Mexico City, 04960. Mexico. email: agustin.orihuela.trujillo@gmail.com

\section{F Napolitano}

Scuola di Scienze Agrarie, Forestali, Alimentari ed Ambientali, Università degli Studi della Basilicata, 85100 Potenza, Italy.

Received: June 19, 2020 • Accepted: July 05, 2020 • Published Online: July 20, 2020

\begin{abstract}
Information on approaches to weaning zebu (Bos indicus) and water buffalo (Bubalus bubalis) calves is scarce in proportion to studies of breeds of B. taurus cattle, whether dairy or beef. Little research has been done to test or validate methods evolved in cattle-ranching to these other species. Hence, expanding our understanding of appropriate, speciesspecific methods of weaning could support the development of approaches or strategies that have the potential to improve animal welfare and productive performance in temperate or tropical climes. This review focuses on traditional and current weaning strategies in an attempt to improve productivity and animal welfare for water buffaloes and zebus. For the case of the water buffalo, it examines common, routine weaning techniques and procedures as well as novel approaches, while for the zebu it discusses abrupt versus gradual and early versus late weaning as strategies and routines usually employed during this process. Finally, it analyses how new weaning techniques may reduce stress while enhancing productivity at the same time. These approaches include fence-line weaning, nose-flaps (plastic devices that prevent the calf from grabbing a teat to suckle), restricted suckling and a section on practical tips to decrease the stress induced by weaning in zebus. A better understanding of certain weaning techniques could, therefore, benefit calf welfare while simultaneously increasing cows' reproductive performance. Unfortunately, data on such approaches is scant, so despite published findings, several key issues remain unsolved living room for additional studies.
\end{abstract}

Keywords: buffalo welfare, fence-line weaning, nose-flaps, restricted suckling, weaning stress, zebu welfare

\section{Introduction}

Zebu (Bos indicus) and water buffaloes (Bubalus bubalis) have been often considered comparable to beef and dairy cattle (Bos taurus), respectively, with most of the techniques developed for the later breeds transferred to the former tropical species without changes or adaptations, although most of the studies on beef and dairy cattle were performed on European breeds and in countries with a temperate/cold climate (Abeygunawardena and Dematawewa 2004; Napolitano et al 2013; Bertoni et al 2019, 2020). However, it should be noted that even though the fundamental physiological aspects might be similar, allowing their classification as large ruminants within the same sub-family (Bovinae), there are substantial differences, so they are classified into different species, with genotypes developed in response to specific environments, resulting in different phenotypes and physiological characteristics (Sartori et al 2010; Mota-Rojas et al 2020a). Important differences between these species call into question that strategies generated in one species, produces the same results when applied to the other. Furthermore, some of the contrasting results found in the literature might be explained based on species differences. One relevant difference is the high mortality rate observed in zebu (Thumbi et al 2013) and buffalo calves (Mora-Medina et al 2018; Mota-Rojas et al 2019; González-Lozano et al 2020; Mota-Rojas et al 2020b) from birth to weaning as compared with beef and dairy cattle, respectively. This represents a significant issue with detrimental effects on animal welfare and farm profitability, which may be caused by weaning techniques inappropriately transferred from cattle to zebu and buffaloes.

Currently, the information regarding weaning procedures in zebu and buffaloes is rather limited compared to that of beef and dairy cattle breeds, and very few works have validated or adapted the techniques developed in cattle to these two species. Therefore, an increase in knowledge of the most 
appropriate weaning techniques to be used may be useful to develop specific protocols or strategies to increase their welfare and production efficiency in temperate and tropical environments.

\section{Weaning in buffaloes}

\section{Common techniques and routine weaning procedures}

Delayed dental eruption and reduced milk intake in water buffalo calves indicate that these animals are less mature than cattle calves at birth and, as a consequence, more sensitive to noxious environmental factors such as pathogens and extreme temperatures (Zicarelli 2006). Due to their tropical origin and consequent sensitivity to low temperatures, these animals are also more susceptible to neonatal diseases than other domestic ruminants, particularly when buffalo cows deliver in the winter (Mingala and Gundran 2008). In addition, due to the mismatch between the reproductive seasonality of buffaloes and the demand for mozzarella cheese, numerous farms in Italy practice the out-of-season breeding technique that entails introducing bulls into the herd only in the April-September period (Di Francesco et al 2011). In both cases -with or without this technique- farms will face periods when parturitions are concentrated and the calf barn will become overcrowded, facilitating disease transmission, morbidity, and mortality.

Common weaning practices in intensive Mediterranean dairy buffalo operations do not differ from those used with dairy cattle. These include early separation of the calves soon after parturition, and administering colostrum (Zicarelli et al 2007). The calf's state of health -indeed, its very survival- can be affected by how colostrum is managed. The same is true for weight gain and growth patterns, since calves are agammaglobulinemic at birth and depend on the IG provided by the dam through her colostrum, which helps protect newborns from pathogens (Godden et al 2019). The colostrum provided must be of sufficient quantity, clean and highquality, and needs to be supplied during the first few hours of life. Providing 3-4 liters (for Holstein calves) of colostrum, or feeding with $10-12 \%$ of colostrum with respect to body weight should be sufficient to protect the neonate. More specifically, each calf needs to ingest a minimum of 150-200 g of IgG after birth. Ideally, $300 \mathrm{~g}$ of $\mathrm{IgG}$ will aid in providing an excellent level of passive transfer (Godden et al 2019). Subsequently, calves should receive increasing amounts of milk substitute (24\% protein, 21\% fat), up to 6-7 liters per day in two separate meals until they reach 4-5 weeks of age (De Rosa et al 2017). At that point, administration of the substitute should be reduced gradually while providing hay and concentrate ad libitum (starting at 7-10 days) in order to wean the calves at about 90 days of age and 80-90 kg of body weight, when they have achieved the capacity to gain at least $800-900 \mathrm{~g}$ of body weight per day (De Rosa et al 2017). Calves should be housed in individual boxes for eight weeks, as stipulated in European legislation on their protection, and then grouped in indoor multiple pens. A survey recently conducted on 70 farms in southern Italy (De Rosa et al 2017) observed that buffalo calves were separated from cows at 3 days, which means that they were allowed to suckle colostrum from their mothers. The maximum amount of milk substitute administered there was 4.8 liters (range 2-8) per day, while administration of hay and concentrate began around 18 days of age. On average, those calves were weaned at 88 days of age (range 60-120) and 77 $\mathrm{kg}$ of body weight (range 50-115) (De Rosa et al 2017). These data indicate that in some cases the calves' requirements were not satisfied before weaning, with consequent negative effects on performances, such as lower than expected body weight. The welfare of buffalo calves also declines when the space destined for weaning is restricted. While restricting this area may reduce the level of economic investment, it could be controversial from the perspective of the requirements of animal welfare (Grasso et al 1999). Grasso et al (1999) observed that a space allowance ranging from 1.0-2.6 $\mathrm{m}^{2}$ /animal did not affect the growth of un-weaned calves, but that many endocrines and immune alterations (e.g. cortisol level, antibody response) were detected as a response to space restrictions. More importantly, those authors noted that providing an outdoor paddock increased the humoral and cellular immune response of calves, a factor that could potentially reduce the mortality rate among young animals. Bharti et al (2015) found that Murrah buffalo calves that were separated from their dams at birth and fed colostrum taken from their mothers, had immunoglobulin levels similar to those of dam-reared calves, but lower daily weight gain. These results indicate the need to ensure early colostrum ingestion in both early-separated and dam-reared buffalo calves to provide good protection against the pathogens that may normally affect them on the farm. However, stress, including that caused by early separation, may impair these humoral and cellular immune responses to novel antigens. This suggests that hygiene and space allowance must be provided at high levels to reduce mortality in this highly-sensitive category of animals (Grasso et al 1999).

Early studies conducted under controlled conditions on an experimental farm in Egypt reported weight gains in control buffalo calves weaned at 120 days that were similar to those seen in calves weaned as early as 45 days (Khary et al 1967). However, more recent work with Egyptian river buffaloes carried out on a commercial farm showed that early weaning may lead to lower growth rates and performance similar to that of calves affected by pathological problems (e.g. diarrhea), or subjected to inappropriate housing conditions (Ali et al 2015). Pakistani Nili-Ravi buffalo calves weaned at 56 days showed lower growth rates than those calves weaned at 84 days of age and, regardless of the age at 
weaning, all calves had lower daily weight gain when offered milk substitute at $10 \%$ vs. $15 \%$ of body weight (Abbas et al 2017). In contrast, dairy buffalo calves in Asia are usually dam-reared right up to the age of weaning, and in the traditional production system, are allowed to suck from one or two teats before and/or after the dam is milked (Kantharaja et al 2018).

Numerous studies of artificial rearing have been conducted, and most report lower growth rates in artificiallyreared buffalo calves (i.e., receiving milk substitute at $10 \%$ of body weight) compared to dam-reared ones (e.g. Bharti et al 2015; Kantharaja et al 2018). Low performance in artificiallyreared calves has also been observed in Australia, where swamp buffaloes are kept in very extensive conditions. There, orphaned calves are reared artificially, but mortality rates may go as high as 25\% (Standing Committee on Agriculture 1995). Those authors suggest a space allowance of $1.5-2 \mathrm{~m}^{2} /$ calf accompanied by frequent handling to minimize the stress of forced interactions with animals unaccustomed to the presence of humans. Lemcke (2015), finally, concludes that dam-reared calves should be weaned at $120-150 \mathrm{~kg}$ of body weight, depending on the availability of feed and the dam's body condition.

\section{Novel weaning strategies}

One hotly-debated topic in the dairy sector, and one to which consumers and citizens are becoming increasingly sensitive, is the early separation of calves from their mothers (Sirovnik et al 2020). In response, novel methods are being developed to extend this period of contact for dairy cattle (Sirovnik et al 2020). No similar studies are yet available for dairy buffaloes, though such ethical issues are beginning to play a fundamental role in orienting the demand for mozzarella cheese, the main product of this sector (De Rosa et al 2015).

As in the case of other newborn ruminants, buffalo calves that fail to ingest sufficient, good-quality colostrum soon after birth, and that do not absorb an adequate amount of immunoglobulins, may have a higher risk of morbidity and mortality throughout the neonatal period, despite the fact that river buffalo colostrum is of higher quality in terms of nutrients than cow colostrum. At calving, buffalo colostrum has higher concentrations of lactose, total solids, fat, ash, vitamin $\mathrm{E}$, phosphorus, and IGF-1, but lower concentrations of lactoferrin, $\mathrm{Mg}$, vitamin $\mathrm{A}, \mathrm{K}, \mathrm{Na}$, and $\mathrm{Zn}$ than cow colostrum (El-Fattah et al 2012). Due to the generally high mortality rates among buffalo calves - perhaps attributable, at least partially, to insufficient immune protection- using esophageal feeders is suggested, mirroring current practice with dairy cattle calves (Adams et al 1985), even though this is associated with slightly lower levels of serum immunoglobulins compared to bottle-feeding, especially at low levels of colostrum ingestion (Godden et al 2009). This result may be attributable to the fact that esophageal feeders introduce the colostrum directly into the rumen instead of into the abomasum, resulting in a 2-4 hr delay before it reaches the intestine (Lateur-Rowet and Breuink 1983) when the permeability of the intestinal walls may be reduced. A second negative aspect is that esophageal feeding requires increased labor, though this may be partially compensated by feeding the calves only once instead of twice a day (Hopkins and Quigley 1997). When using esophageal feeding, care should be taken to reduce the risk of lesions to the oral-esophageal tract (epiglottis, larynx, pharynx, etc.), and of insertion into the trachea that will allow milk to enter the lungs.

Due to the concentration of parturitions in certain periods of the year, and the high costs of milk substitutes, the workforce employed on some buffalo farms may be insufficient to appropriately care for young calves. Therefore, as with cattle (Gleeson et al 2007), Vecchio et al (2013) and, more recently, De Martino et al (2018) have suggested that the milk substitute be administered once instead of twice a day, as a single administration at a double concentration (36\% DM) generated growth rates and haptoglobin, lysozyme and bactericide activity levels similar to those observed in calves that received two meals a day with a normal concentration (18\% DM) throughout the weaning period (90 days).

Recently, Serrapica et al (2019) conducted a trial to verify whether the development of pre-stomachs could be stimulated in order to reduce the weaning age of calves and so increase farm profitability. The calves in their study were offered, ad libitum, either long hay $(20 \mathrm{~cm})$ plus commercial pelleted starter, chopped hay $(3-4 \mathrm{~cm})$ plus commercial pelleted starter, or commercial pelleted starter alone, from day 15 of life. The chopped hay option increased the dimensions of the stomach and reduced non-nutritive oral behaviors compared to the other two conditions. However, the calves that received chopped hay plus starter showed reduced growth, possibly because they spent less time eating the starter. In this study, the highest daily weight gains were shown by the calves that ate only starter. These results indicate that although the latter dietary treatment may increase growth rates and reduce the weaning age, in the longer term higher fiber ingestion probably stimulates pre-stomach development -as observed in the calves that were fed chopped hay plus starter- while also enhancing the performance of the weaned animals. A previous study reported lower weight gains by free-ranging buffalo heifers kept on pasture that ingested a higher proportion of fiber than a control group of confined animals that consumed greater quantities of concentrated feeds. In that case, no between-group differences were observed in terms of age at puberty (Sabia et al 2014). The authors interpreted their results as showing a more efficient utilization of nutrients by the buffaloes that were fed more fibrous kinds of feed. 


\section{Weaning in zebu}

\section{Common strategies and routine weaning handling}

The average age of natural weaning in zebu cattle has been reported around 10 months with a marked sex difference. Female calves are prevented by their mothers from suckling after an average age of 8.8 months, but male calves continued to be suckled for a further 2.5 months and are weaned at an average age of 11.3 months (Reinghardt and Reinghardt 1981). However, in artificial weaning, calves are separated from their mothers in general between five to eight months, regardless of the sex of the calf.Abrupt weaning

Abrupt weaning is the most common weaning strategy and consists in the separation of the calves from their mothers to another pasture beyond the reach of sight, smell, and hearing of their dams. In general, it is carried out when calves are between five to eight months of age, after the lactation peak when calves are already grazing.

In general, abrupt cow-calf separation causes acute stress reactions like an increase in vocalizations, pacing, and blood cortisol responses, but most stress indicators in cows and calves decrease after $48 \mathrm{~h}$ of separation (Acevedo et al 2005). Cows seem to be less affected than their young, and older calves display fewer signs of stress than younger animals (Pérez-Torres et al 2016).

\section{Early weaning}

In European beef cattle, early weaning can be performed when calves are three months old and is most commonly performed when calves are about five months. However, there is some information of weaning calves as early as two months (Monje et al 1993). It consists in the artificial definite separation of cows and calves at an early age postpartum, regardless of the method used. Instead of abrupt separation, some management techniques used in order to reduce the stress of the final separation commonly known as two-stages weaning (i.e. fence-line, nose-flaps or restricted suckling) could be applied. However, there is only limited information in zebu cattle on abrupt early weaning.

Early weaning has been shown to be an effective mean for improving Brahman-crossbred cows reproduction (Arthington and Kalmbacher 2003), taking advantage of the shortening of the interval from partum to first ovulation induced by removing the nutrient requirements associated with lactation (Wyatt et al 1977) and the presence of the calf (Randel 1981). In general, early weaning results in an increase in cow body weight and body condition score (GalindoGonzalez et al 2007). The procedure seems especially beneficial under conditions of low forage production seasons, as a better utilization of limited feed and as a drought management tool (Arthington and Kalmbacher 2003).
The effects of early weaning on productivity of thin, Brahman-crossbred primiparous cows was studied by Arthington and Minton (2004). They found a substantial reduction in the amount of total digestible nutrients required to support cow body weight gain in cows from which calves were removed at 93 days postpartum (dpp), in addition to reduction in the interval partum to first ovulation. They conclude that early weaning is a convenient strategy to recovery of the thin cow after parturition, and for the reduction in calving intervals. In contrast, Carcedo et al (2007) concluded that early weaning did not affect the reproductive maturity or performance of crossbred zebu heifers grown under rangeland conditions when bred at two years old.

Regarding the calves, Monje et al (1993) found a similar weight gain pattern in two to five months old European beef type calves, when compared early weaned calves at two months of age with those under continuous suckling. However, Coppo (2007) found that calves weaned at two to three months of age, weighing no less than $70 \mathrm{~kg}$ at the age of weaning, were about $20 \mathrm{~kg}$ less than those under continuous suckling. This author hypothesized that this weight difference was due to the separation stress suffered by the calves during early weaning. However, when he delved into the subject, these authors concluded that even though early weaning induces some stressful reactions during mother-young separation, the main problem of the weight difference was an under-nutrition stage, that might be reduced by the use of high digestibility foods offered to the recently weaned calves, particularly those in younger ages. It seems that the stress induced by the early weaning procedure, at least in $B$. taurus cattle, is more serious the lower the quantity and quality of the available forage and the lower the weaning age (Renner 1991; Galli et al 1995). However, these has not been documented in $B$. indicus cattle, and the potential negative impact on calf welfare caused by emotional stress due to maternal deprivation also needs further investigation in European and tropical species.

\section{Novel weaning strategies}

There is no doubt that the weaning transition period can be stressful time for calves and cows, and management strategies to improve their wellbeing during this period are being investigated.

In general, these strategies involve separating the termination of suckling from the social separation of the calfdam pair, for example by keeping the calves separated from the dams through fence-line contact for a period before the final separation (Price et al 2003) or with the aid of nose-flaps (Haley 2005) that allow social contact but not suckling. Procedures that, again, have been little studied in the tropics. 
Fence-line

Evidence from European beef cattle suggests that separating mothers and young partially by allowing them to make contact across a fence for a period before complete separation is less traumatic than suddenly separating them completely. Although economic advantages may vary between years and depend upon how soon calves are sold after weaning, contact weaning systems show promise for reducing stress when animals are separated to induce weaning.

The results shown in zebu cattle by Pérez-Torres et al (2017) using fence-line weaning support the hypothesis that fence-line contact between mother and young at weaning results in fewer indices of behavioral distress than total abrupt separation of calves from their dams, and minimizes reductions in weight gain often associated with weaning.

In the fence-line weaning study conducted by Price et al (2003) in B. taurus cattle, they found that most of the calves graze together away from the fence and then return to stand or lie down near the fence, with the distance traveled increasing over days following separation. This synchronized grazing and resting behaviors exhibited for three days, is consistent with the hypothesis that social bonds between calves are strengthened at weaning and that calf groups tend to behave as a unit. Veissier and LeNeindre (1989) showed that B. taurus weaned calves gather and have more social encounters with one another than similar-age calves which remained with their mothers. This cohesion within recently weaned calves might be a way to cope with the recently broken relation with their mothers and function as a social buffering, reducing the stress in the calves. Price et al (2003), using Angus/Herford cattle also found differences for cumulative weight gain over the 10weeks post-weaning period between calves that were separated from their mothers via fence-line in comparison with those that were abruptly separated from their dams to a non-contiguous pasture, with treatment differences greater in the weeks immediately following weaning than later. At two weeks post-weaning, fence-line weaning calves had gained $95 \%$ more weight than the average calf in the abruptly separated group. At 10 weeks post-weaning, fence-line weaned calves were still about 10 to $11 \mathrm{~kg}$ heavier than calves in the separated treatments. Nicol (1977) and Stookey et al (1997) also compared post-weaning growth and behavior of calves that had either fence-line contact with their dams or were abruptly and completely separated at weaning. In both studies, the fence-line contact calves initially gained more weight than the abruptly separated calves, but after two to three days there was no difference between treatments.

In zebu cattle, no data have been published about the use of this practice. However, anecdotal information suggest that caution should be taken particularly with cows raised under extensive conditions with very few management and human contact, as these animals might be very sensitive to the call of the calves, particularly at ages $<120$ days old (PérezTorres et al 2014) and might destroy fences in an attempt to maintain contact with their offspring.

According to the results in B. taurus breeds like Angus, fence-line weaning could be a management strategy that not only improves animal welfare but also may economically benefit cattle producers, especially those who sell their calves in the days or weeks following weaning. However, it is necessary to conduct research in zebu cattle using this weaning strategy, because there is a possibility that the results may be different from those expected. For example, Solano et al (2007) studied behavioral responses of zebu-type calves to short-term separation and found that this practice induces severe psychological stress, while preventing any sensorial contact between mother and young within this period resulted in a less stressful.

Nose-flaps

Temporarily fitting the young with an anti-sucking device that allows them to eat solid food but not to suckle (Haley 2005) prompts the young to adjust to solid food consumption without the concurrent stressors of removal from the mother and exposure to novel housing conditions (Figure 1). In B. taurus breeds it has been demonstrated that previous exposure of calves to two-step weaning with the use of nose flaps reduced distress at weaning time. Even though there is no information in the scientific literature validating this method in zebu calves, the results from experiments in European breeds suggest that use of nose-flaps before separation strongly motivates the calves to consume solid food, which can lead to improved weight gains.

Although previous work in B. taurus cattle has implied that both two-step weaning methods, fence-line and nose-flaps weaning, result in a reduction in overall distress behavior associated with weaning in beef calves (Price et al 2003; Haley et al 2005; Quintans et al 2008). Ungerfeld et al (2010) suggest that there is no overall reduction but rather a redistribution over two periods. Latham and Mason (2008) argue that preventing suckling from a present cow results in numerous failed attempts that might generate frustration in the calves, and suggested caution when choosing these methods.

In addition, to the possible differences between breeds, many factors such as: duration of the nose-flap treatment (Haley et al 2005), cow's milk production (Hötzel et al 2010), age of the calves (Ungerfeld et al 2009), and climate (Pollard and Littlejohn 2000), might influence the response to weaning, and could explain contrary results.

Combining the use of anti-suck devices followed by fence line contact at separation may be optimal (Haley 2005) in European cattle. However, no studies have been conducted in zebu type cattle, and the contradictory results urge for more research in this area. 


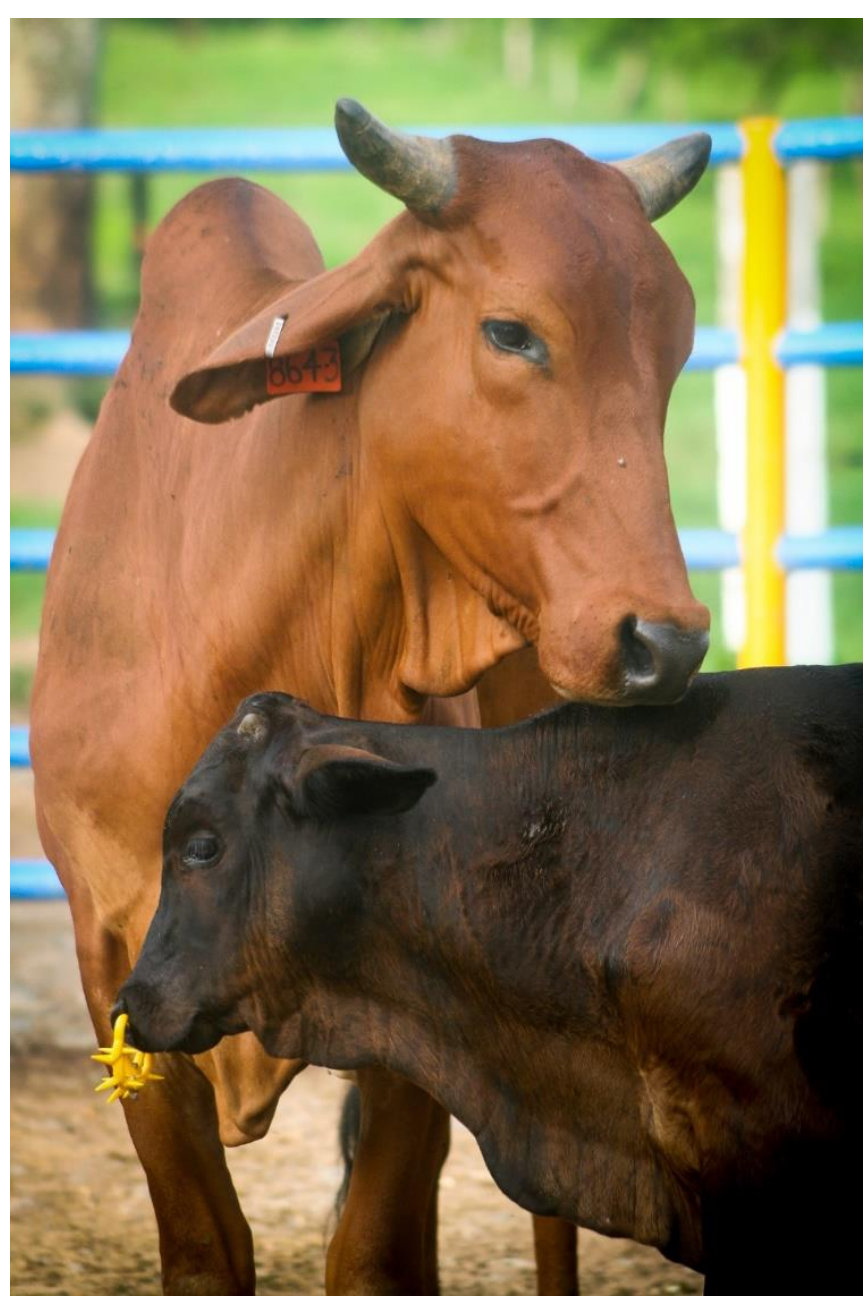

Figure 1 The device observed in the picture prevents the calf from suckling, forcing him to eat solid food, before breaking the bond with his mother. Although little studied, the method aims to reduce calf suffering by segregating the factors that generate stress during weaning.

\section{Restricted suckling}

Restricted suckling is the method where there is a little more research on zebu cattle, perhaps because of the advantages that it offers as an effective procedure to shorten the calving interval, without shortening the duration of lactation. In an early study, Bastidas et al (1984) used Brahman cows and first-calf heifers undergoing a twice-daily suckling (45 minutes of suckling each time) from 30 days post-partum until weaning at seven months, and found that the mean pregnancy rate was $63.06 \pm 0.06 \%$ and was influenced by nursing and number of parturitions. The pregnancy rate was $33 \%$ higher in twice-daily suckled cows. Forty-four percent of the first calf heifers in the twice-daily suckling group became pregnant compared to $9 \%$ in the control group without depressing pre-weaning calf performance. Similarly, in a more recent study, Perez-Torres et al (2017) found that calves subjected to mother deprivation during the suckling period displayed fewer behavioral distress signs, diminished cortisol response and higher body weights during the first days after weaning and at 270 days of age, with a tendency for calves separated for longer periods from their dams to achieve larger weights. Pérez-Torres et al (2017) suggested that the fast recovery of most behavioral indicators of stress in the treated calves after the initial acute response could be explained by a greater nutritional independence of these calves, as shown by a greater willingness to graze than control calves, particularly those calves that were previously temporarily separated from their mothers for $72 \mathrm{~h}$ in comparison with $24 \mathrm{~h}$.

The combined stress caused by the restricted suckling period and definitive weaning, in combination or not with the use of nose-flaps or fence-line, have not been done with zebu cattle, and it is unknown how these combined events will alter behavioral and physiological responses immediately after weaning or later in life.

Table 1 summarizes soe of the weaning strateties described above and their impact on animal welfare and productivity.

Practical tips to decrease weaning stress

Feed calves some post-weaning supplement while they are still with the cow. For example, if calves are going to be given silage after weaning, feeding silage to the cow-calf dyads a few times before weaning could be advantageous. Even if calves are being weaned onto good quality pasture, having some of their diet the same before and after weaning, can help them with the change.

Rumen microbial populations can require up to 14 days to completely adapt to a new diet. Consider introducing calves to post-weaning supplements slowly via creep-feeding two weeks before weaning.

Deworming calves prior to weaning, may produce heavier and healthier calves at weaning (Hersom et al 2011).

Avoid combining stressful procedures like castration or branding with weaning. Weaning itself is a stressful procedure and subjecting a calf to further stress, notably harms their welfare.

Keep weaned calves as a group, in familiar environments, old enough to and habituated to solid food.

Wean calves as old as possible. Older calves display less signs of stress than young animals (Pérez-Torres et al 2016).

Giving calves access to a silvo-pastoral system at the time of weaning has beneficial effects on the live weight change of both the calves and their dams, and supplementation of the calves during the weaning period provides further benefits (Mahecha et al 2004). 
Table 1 Summarize of weaning strategies and their impact on animal welfare and productivity.

\begin{tabular}{ll}
\hline Strategy & Impact on animal welfare and productivity \\
\hline Early weaning & Poor animal welfare; low weight gains; health problems; milk \\
& $\begin{array}{l}\text { production; milk is for sale or cheese production; shortens the } \\
\text { interval from partum to first ovulation }\end{array}$
\end{tabular}

Abrupt weaning

Fence-line

Nose-flaps

Anti-suck devices followed by fence-line contact at separation

Restricted suckling
Causes acute stress reactions for $48-72 \mathrm{~h}$; younger calves are more affected than older calves

Fewer indices of stress and better weight gains than abrupt separation; caution should be taken with poorly managed animals that can break fences to reunite

No studies in buffaloes or Zebu cattle; studies from Bos taurus suggests that use of nose-flaps before separation strongly motivates the calves to consume solid food, which can lead to improved weight gains and reduce stress at the time of separation

No studies in buffaloes or Zebu cattle

Shortens of calving interval, without shortening the duration of lactation; great diversity of procedures; twice-daily suckling (45 min of suckling each time) favors the reproduction of cows and seems to have no serious repercussions on the young

\section{Final Considerations}

Most of the weaning methods apply in zebu and water buffaloes have been developed in B. taurus breeds, and very few have been validated in the tropics. The knowledge of specific weaning methods might contribute to enhance the welfare of the offspring and to improve the reproductive efficiency of the cow. However, there is still little information available about such strategies. By now, even though there are some results available, there are many questions without answers, leaving the field open for the development of future research.

\section{Conflict of Interest}

The authors declare that there are no conflict of interest with this work.

\section{References}

Abbas W, Bhatti SA, Khan MS, Saeed N, Warriach HM, Wynn P, McGil D (2017) Effect of weaning age and milk feeding volume on growth performance of Nili-Ravi buffalo calves. Italian Journal of Animal Science 16:490-499.

Abeygunawardena H, Dematawewa CMB (2004) Pre-pubertal and postpartum anestrus in tropical zebu cattle. Animal Reproduction Science 82-83:373-387.

Acevedo N, Hernández C, Orihuela A, Lidfors LM, Berg C (2005) Effect of restricted suckling or temporal weaning on some physiological and behavioural stress parameters in zebu cattle (Bos indicus). Asian-Australasian Journal of Animal Science 18:11761181.
Adams GD, Bush LJ, Horner JL, Staley TE (1985) Two methods for administering colostrum to newborn calves. Journal of Dairy Science 68:773-775.

Ali MA, El-khodery SA, El-Said WE (2015) Potential risk factors associated with ill-thrift in buffalo calves (Bubalus bubalis) raised at smallholder farms in Egypt. Journal of Advanced Research 6:601607.

Arthington JD, Kalmbacher RS (2003). Effect of early weaning on the performance of three-year-old, first-calf beef heifers and calves reared in the subtropics. Journal of Animal Science 81:1136-1141.

Arthington JD, Minton JE (2004). The effect of early calf weaning on feed intake, growth, and postpartum interval in thin, Brahmancrossbred primiparous cows. Applied Animal Science 20:34-38.

Bastidas P, Troconiz J, Velarde O, Silva O (1984). Effect of restricted suckling on pregnancy rates and calf performance in Brahman cows. Theriogenology 21:289-294.

Bertoni A, Napolitano F, Mota-Rojas D, Sabia E, Alvarez-Macias A, Mora-Medina P, Morales-Canela DA, Berdugo J, GuerreroLegarreta I (2020) Similarities and differences between river buffaloes and cattle: anatomical, physiological and productivity aspects. Journal of Buffalo Science 9: In press.

Bertoni MA, Álvarez MAG, Mota-Rojas D (2019) Desempeño productivo de los búfalos y sus opciones de desarrollo en las regiones tropicales. Sociedades Rurales Producción y Medio Ambiente 38:5980 .

Bharti PK, Dutt T, Patel M, Pandey HO (2015). Success rate, growth performance and feed efficiency of buffalo calves reared at different feeding programs under semi-intensive systems of rearing. Indian Journal of Animal Science 85:320-323.

Carcedo-Orallo JA, Alonso-Toniolo A, Menajovsky-Barbiero JR, Álvarez-Verzeroli CF (2007) Effect of early weaned calves on the 
reproductive performance in heifers mating at two years old. Archivos Lationoamericanos de Producción Animal 16:13-17.

Coppo JA (2007). Multivariate analysis about causes of growth delay in early weaned calves. Revista Veterinaria 18:37-45.

De Martino L, Sibillo F, Faggiano A, Musco N, Tudisco R (2018) Influence of the number of milk replacer administrations on the in vivo performance of bovine and buffalo calves. Journal of Nutrition Ecology and Food Research 5:9-19.

De Rosa G, Grasso F, Pisani M, Salese M, Serrapica M, Napolitano F (2017) Cross-sucking and inter-suckling in dairy buffaloes. Proceedings of the 7th International Workshop on Assessment of Animal Welfare at Farm and Group Level. 5-8 September, Ede, The Netherlands, 247.

De Rosa G, Grasso F, Winckler C, Bilancione A, Pacelli C, Masucci F, Napolitano F (2015) Application of the Welfare Quality ${ }^{\circledR}$ protocol to dairy buffalo farms: prevalence and reliability of selected measures, Journal of Dairy Science 98:6886-6896.

Di Francesco S, Boccia L, Campanile G, Di Palo R, Vecchio D, Neglia G, Zicarelli L, Gasparrini B (2011) The effect of season on oocyte quality and developmental competence in Italian Mediterranean buffaloes (Bubalus bubalis), Animal Reproduction Science 123:48-53.

El-Fattah AA, Abd Rabo FHR, El-Dieb SM, El-Kashef HA (2012). Changes in Composition of Colostrum of Egyptian Buffaloes and Holstein Cows. BMC Veterinary Research, 5:8-19.

Galindo-Gonzalez S, Arthington JD, Yelich JV, Hansen GR, Lamb GC, De Vries A (2007). Effects of cow parity on voluntary hay intake and performance responses to early weaning of beef calves. Livestock Science 110:148-153.

Galli IO, Monje AR, Hofer CC (1995) Destete precoz: clave para nuevos sistemas de producción de carne vacuna en la Provincia de Corrientes, Ed. INTA Concepción del Uruguay (Argentina), 33 p. (In Spanish).

Gleeson D, O'Brien B, Fallon RJ (2007) Feeding of cold whole milk once daily to calves in a group and its effect on calf performance, health, and labor input. International $\mathrm{J}$ of Applied Research in Veterinary Medicine 5:97-104.

Godden SM, Haines DM, Konkol K, Peterson J (2009). Improving passive transfer of immunoglobulins in calves. II: Interaction between feeding method and volume of colostrum fed. Journal of Dairy Science 92:1758-1764.

Godden SM, Lombard JE, Woolums AR (2019) Colostrum Management for Dairy Calves. Vet Clin North Am Food Anim Pract 35:535-556.

González-Lozano M, Mota-Rojas D, Orihuela A, Martínez-Burnes J, Di Francia A, Braghieri A, Berdugo J, Mora MP, Napolitano F (2020) Behavioral, physiological, and reproductive performance of buffalo cows during eutocic and dystocic parturitions. Applied Animal Science 36:407-22.

Grasso F, Napolitano F, De Rosa G, Quarantelli T, Serpe L, Bordi A (1999). Effect of pen size on behavioral, endocrine and immune responses of water buffalo (Bubalus bubalis) calves. Journal of Animal Science 77:2039-2046.

Haley DB, Bailey DW, Stookey JM (2005) The effects of weaning beef calves in two stages on their behavior and growth rate. Journal of Animal Science 83:2205-2214.
Hersom MJ, Myer RO, Carter JN (2011) Influence on weaning weights of nursing beef cattle calves de-wormed 90 days prior to weaning. Livestock Science 136:270-272.

Hopkins BA, Quigley JD (1997) Effects of method of colostrum feeding and colostrum supplementation on concentrations of immunoglobulin $\mathrm{G}$ in the serum of neonatal calves. Journal of Dairy Science 80, 979-983.

Hötzel MJ, Ungerfeld R, Quintans G (2010) Behavioral responses of 6-month-old beef calves prevented from suckling: influence of dam's milk yield. Animal Production Science 50:909-915.

Kantharaja KJ, Tomar AKS, Nataraju OR, Naveen Kumar BT (2018) Early growth performance comparison of weaned and suckling Murrah buffalo calves under institutional situations. International Journal of Current Microbiology and Applied Sciences 7:723-733.

Khoury FK, Ahmed IA, Ei-Shazly K (1967) Early Weaning in Cow and Water Buffalo Calves (Bos bubalus L.). I. Growth Rates, Efficiency of Feed Utilization, and Cost of Unit Gain. Journal of Dairy Science 50:1661-1666.

Lateur-Rowet HJM, Breuink HJ (1983) The failure of the oesophageal groove reflex, when fluids are given with an oesophageal feeder to newborn and young calves. Veterinary Quarterly 5:68-74.

Latham NR, Mason GJ (2008) Maternal deprivation and the development of stereotypic behavior. Applied Animal Behaviour Science 110:84-108.

Lemcke B (2015) Weaning water buffalo calves - Recommended Practice for all Buffalo Producers. Agnote, J89:1-4.

Mahecha L, Giraldo D, Arroyave JF, Restrepo LF (2004) Silvopastoral systems as an alternative for early weaning of Zebu calves. Livestock Research for Rural Development 16:5.

Mingala CN, Gundran RS (2008) Assessment of water buffalo health and productivity in a communal management system in the Philippines. Tropical Animal Health and Production 40:61-68.

Monje AR, Hofer CC, Galli IO (1993) Destete precoz: efecto sobre los vientres, manejo de los terneros e impacto de la técnica sobre los sistemas de producción. Memorias Jornada de difusión técnica destete precoz en cría vacuna. INTA EEA C del Uruguay:13-38. (In Spanish)

Mora-Medina P, Napolitano F, Mota-Rojas D, Berdugo-Gutiérrez J, Ruiz-Buitrago J, Guerrero-Legarreta I (2018) Imprinting, sucking and allosucking behaviors in Buffalo calves. Journal of Buffalo Science 7:49-57.

Mota-Rojas D, De Rosa G, Mora-Medina P, Braghier A, GuerreroLegarreta I, Napolitano F (2019) Invited review: Dairy buffalo behaviour and welfare from calving to milking. CAB Reviews 14:112.

Mota-Rojas D, Napolitano F, Bertoni MA, Gómez-Prado J, MoraMedina P, Monterrosa CR, Guerrero-Legarreta I (2020a). Thermal biology in river buffalo in the humid tropics: neurophysiological and behavioral responses. International Journal of Veterinary Science and Medicine 8: (Accepted).

Mota-Rojas D, Martínez-Burnes J, Napolitano F, Domínguez MN, Guerrero-Legarreta I, Mora-Medina P, Ramírez NR, González LM (2020b). Invited review: Dystocia: Factors affecting parturition in domestic animals. CAB Reviews 15:1-14.

Napolitano F, Pacelli C, Grasso F, Braghieri A, De Rosa G (2013). The behaviour and welfare of buffaloes (Bubalus bubalis) in modern dairy enterprises. Animal 7:1704-13. 
Nicol A (1977). Beef cattle weaning methods. New Zealand Journal of Agriculture 134:17-18.

Pérez-Torres L, Orihuela A, Corro M, Rubio I, Alonso MA, Galina CS (2016). Effects of separation time on behavioral and physiological characteristics of Brahman cows and their calves. Applied Animal Behaviour Science 179:17-22.

Pérez-Torres LI, Orihuela A, Corro M, Rubio I, Cohen A, Galina CS (2014) Maternal protective behavior of zebu type cattle (Bos indicus) and its association with temperament. Journal of Animal Science 92:4694-4700.

Pérez-Torres LI, Orihuela A, Galina CS, Rubio I, Corro M, Cohen A, Hernández A (2017). Effect of different periods of maternal deprivation on behavioral and cortisol responses at weaning and subsequent growth rate in zebu (Bos indicus) type cattle. Livestock Science 197:17-21.

Pollard JC, Littlejohn RP (2000) Effects of management at weaning on behavior and weight gain of farmed red deer calves. Applied Animal Behaviour Science 67:151-157.

Price EO, Harris JE, Borgwardt RE, Sween ML, Connor JM (2003) Fence-line contact of beef calves with their dams at weaning reduces the negative effects of separation on behavior and growth rate. Journal of Animal Science 81:116-121.

Quintans G, Banchero G, Ungerfeld R (2008) Reducción del estrés del destete en terneros de razas carniceras: efecto del pretratamiento con tablilla nasal o alambrado por medio sobre el destete definitivo. First Congress of Latin America Region of the International Society for Applied Ethology, Montevideo, p. 44 (abstr.).

Randel RD (1981). Effect of once daily suckling on postpartum interval and cow-calf performance of first calf Brahman x Hereford heifers. Journal of Animal Science 53:755-757.

Reinhardt V, Reinhardt A (1981) Natural sucking performance and age of weaning in zebu cattle (Bos indicus). Journal of Agricultural Science Cambridge 96:309-313.

Renner JE (1991) Los Terneros. Hemisferio Sur, Buenos Aires, 66 p.

Sabia E, Napolitano F, De Rosa G, Terzano GM, Barile VL, Braghieri A, Pacelli C (2014) Efficiency to reach age of puberty and behaviour of buffalo heifers (Bubalus bubalis) kept on pasture or in confinement. Animal 8:1907-1916.

Sartori R, Bastos MR, Baruselli PS, Gimenes LU, Ereno RL, Barros CM (2010) Physiological differences and implications to reproductive management of Bos taurus and Bos indicus cattle in a tropical environment. Proceedings of the $8^{\text {th }}$ international symposium on reproduction in domestic ruminants. Society of Reproduction and Fertility 67:4-22.

Serrapicad M, Braghierid A, Napolitanod F, D'Angelod G, Serrapicad F, Pacellid CD (2019) Effect of fibre length and amount of growth and behavior of buffalo calves. Italian Journal of Animal Science 18(Suppl. 1):161-162.
Sirovnik J, Barth K, de Oliveira D, Ferneborg S, Haskell M, Hillmann E, Jensen MB, Mejdell CM, Napolitano F, Vaarst M, Verwer CM, Waiblinger S, Zipp KA, Johnsen JF (2020) Cow-calf contact I: Terminology and definitions - a position paper. Journal of Dairy Research, in press.

Solano J, Orihuela A, Galina CS, Aguirre V (2007). A note on behavioral responses to brief cow-calf separation and reunion in cattle (Bos indicus). Journal of Veterinary Behavior 2:10-14.

Standing Committee on Agriculture (1995) Model Code of Practice for the Welfare of Animals - Farmed Buffalo. SCARM Report 52, CSIRO Publishing, Collingwood Victoria, Australia.

Stookey JM, Schwartzkopf-Fenswen KS, Walt CS, Watts JM (1997) Effects of remote and contact weaning on behavior and weight gain of beef calves. Journal of Animal Science 75 (Suppl. 1):157 (Abstr.).

Thumbi SM, Bronsvoort MBMdec, Kiara H, Toye PG, Poole J, Conradie Ll, Jennings A, Handel IG, Coetzer JAW, Steyl J, Hanotte O, Woolhouse EJ (2013). Mortality in East African shorthorn zebu cattle under one year: predictors of infectious-disease mortality. BMC Veterinary Research 9;175.

Ungerfeld R, Quintans G, Enríquez DH, Hötzel MJ (2009) Behavioural changes at weaning in 6-mo beef calves reared by cows of high or low milk yield. Animal Production Science 49:637-642.

Ungerfeld R, Quintans G, Guidoni AL, Hötzel MJ (2010) Alternative weaning methods on behavior in beef calves. Livestock Science 128:20-27.

Vecchio D, Di Palo R, De Carlo E, Esposito L, Presicce GA, Martucciello A, Chiosi E, Rossi P, Neglia G, Campanile G (2013) Effects of milk feeding, frequency and concentration on weaning and buffalo (Bubalus bubalis) calf growth, health and behavior. Tropical Animal Health and Production 45:1697-702.

Veissier I, LeNeindre P (1989) Weaning in calves: Its effects on social organization. Applied Animal Behaviour Science 24:43-54.

Wyatt RD, Whettemann RP, Gould MB, Knori L, Totusek R (1977) Effect of single vs. twin rearing on cow and calf performance. Journal of Animal Science 45:1409-1414.

Zicarelli F, Grassi C, Gazaneo MP, Masiello I, Vecchio D, Campanile G (2007) Starter protein concentration and weaning of buffalo calf. Italian Journal of Animal Science 6 (Suppl 1):515-517.

Zicarelli L (2006) Buffalo calf weaning and production. In: Proceedings of the $3^{\text {rd }}$ Simposio de Búfalos de las Américas $-2^{\text {nd }}$ Simposio de Búfalos Europa-América, Medellín, Colombia, 2006, 80-86. 